\title{
Microgrid hálózatok felépítése
}

\author{
Lipták Róbert \\ PhD hallgató, Miskolci Egyetem, Fizikai és Elektrotechnikai Intézet \\ Elektrotechnikai és Elektronikai Intézeti Tanszék \\ 3515, Miskolc, Miskolc-Egyetemváros, e-mail: elkrobi@uni-miskolc.hu \\ Bodnár István \\ intézeti tanszékvezető egyetemi docens, Miskolci Egyetem, Fizikai és Elektrotechnikai Intézet \\ Elektrotechnikai és Elektronikai Intézeti Tanszék \\ 3515, Miskolc, Miskolc-Egyetemváros, e-mail: vegybod@uni-miskolc.hu
}

\begin{abstract}
Absztrakt
A jelenlegi villamosenergia-ellátási rendszer hátránya az, hogy a termelés és nagy távolságra való szállitás következtében kedvezötlen a rendszer hatásfoka, továbbá teljes áramkimaradás miatt a rendszer sebezhetö. Az intelligens hálózatok célja, hogy orvosolja a jelenlegi hálózat jelentös gyengeségeit és lehetöséget teremtsen a szolgáltatásban résztvevöknek, hogy folyamatos információ legyen a hálózati elemekröl, valamint a hálózat állapotáról és a müködéséről. A Microgrid hálózatok rendelkeznek kommunikációs hálózattal, valamint vezérlörendszerrel is, amely lehetövé teszi a rendszer szabályozását. Az intelligens Microgrid hálózatok struktúráját úgy tervezik meg, illetve alakítják ki, hogy csatlakoztatható, valamint leválasztható legyen a közüzemi villamos hálózatról, ezáltal az intelligens vezérlö rendszer lehetöséget biztosit arra, hogy a villamosenergia termelése és annak felhasználása optimalizálva legyen.
\end{abstract}

Kulcsszavak: microgrid hálózat, intelligens hálózat, microgrid hálózatok felépitése,

\section{Abstract}

The disadvantage of the current electricity supply system is that the efficiency of the system is unfavorable due to production and long-distance transmission, and the system is vulnerable due to a complete power outage. The purpose of smart grids is to remedy the significant weaknesses of the current network and to enable service participants to have continuous information about the network elements and the status and operation of the network. Microgrid networks have a communication network as well as a control system. The structure of the intelligent Microgrid networks is designed and constructed to be able to connect and disconnect from the utility electricity network, thus the intelligent control system provides an opportunity to optimize the production and use of electricity as much as possible.

Keywords: microgrid, smartgrid, architecture of Microgrids

\section{Bevezetés}

A váltakozó feszültégü villamosenergiának alapvetően két fö jellemzője van, az egyik, hogy könnyen szállítható nagy távolságokon, a másik pedig az, hogy nem tárolható könnyen. Ennek eredményeként a hagyományos rendszerekben pontosan annyi villamosenergiát kell előállítani, mint amennyire éppen akkor szükség van. Ez a tény arra késztette a kutatókat és mérnököket, hogy a villamosenergiát egy 
olyan „szolgáltatási energiának” tekintsék, amely bármilyen energiaforma átalakításágból származhat, a felhasználás helyén pedig az átalakítása teljesen más formában történhet. Tehát ezen koncepció szerint a hagyományos villamosenergia-rendszert nagyon összetett és széles infrastruktúrának alakították ki, amely lehetővé teszi az energia termelését nagyon nagy távolságban attól a helytől, ahol arra szükség van [1].

\section{Hagyományos villamos hálózatok}

Mint bármely más fizikai rendszer esetén, a villamos hálózaton (felsővezetékek és a kábelek) is veszteség keletkezik, ezért ezek hosszát minimalizálni kell a rendszer energiahatékonyság-növelésének érdekében. Figyelembe véve, hogy a hőveszteség arányos a villamos hálózaton folyó áram négyzetével, valamint a teljesítmény a feszültség és az áram szorzata, ezért nyilvánvaló, hogy minél kisebb az áram, annál nagyobb az energiahatékonysága az egész hálózatnak. Ebből adódik, hogy a villamos hálózatot a lehető legnagyobb feszültségszinten kell működtetni. A távvezetékeken, illetve földkábelen megoldható a magasabb feszültségszint, de nyilvánvalóan a lakossági felhasználásban ez nem lehetséges életvédelmi okok miatt. A villamosenergia-hálózat teljes topológiáját tekintve, nagyon széles feszültségtartomány figyelhető meg, amelynek az értéke attól függ, hogy az energia elosztás mely szintjét tekintjük. [1]

\subsection{Hálózatok feszültségszintjei}

A hálózatok feszültségszintjétől függően megkülönböztetünk kisfeszültségű (1.000 V alatti) és nagyfeszültségü (1.000 V és annál nagyobb) hálózatokat. A szabványos feszültségszintek hazánkban: kisfeszültség a $0,4 \mathrm{kV}$ (ill. $230 \mathrm{~V}$ fázisfeszültség); nagyfeszültség a $3 \mathrm{kV}, 6 \mathrm{kV}, 11 \mathrm{kV}, 22 \mathrm{kV}, 37,5 \mathrm{kV}$, $132 \mathrm{kV}, 220 \mathrm{kV}, 440 \mathrm{kV}, 750 \mathrm{kV}$, - amely értékek alatt mindig a háromfázisú váltakozófeszültségü rendszer vonali feszültsége értendő. Az $1 . . .100$ kV-os hálózatokat a gyakorlati szóhasználatban középfeszültségü hálózatoknak szokás nevezni. A kisfeszültségü hálózatok rendeltetése mindenkor a villamosenergia közvetlen elosztása a fogyasztók között, ezért ezeket a hálózatokat összefoglalóan kisfeszültségü elosztóhálózatoknak nevezzük. A hazánkat tekintve hálózatokat az alábbiak szerint lehetséges felosztani.

\subsubsection{Elosztóhálózat}

Rendeltetése a villamosenergia nagyfeszültségen való elosztása az alállomások gyüjtősíneitől a fogyasztói transzformátorokig. Ezek feszültségszintje hazánkban $11 \mathrm{kV}$ és $22 \mathrm{kV}$ (közcélú, áramszolgáltatói elosztóhálózatok) valamint $3 \mathrm{kV}$ és $6 \mathrm{kV}$ (ipartelepek belső elosztóhálózatai), ezért szokás e hálózatokat középfeszültségủ elosztó hálózatnak is nevezni [5].

\subsubsection{Föelosztóhálózat}

Rendeltetése a villamosenergia elosztása az alaphálózati csomópontokból az elosztóhálózatok táppontjaihoz, amelyek általában a fogyasztói körzetek súlypontjában helyezkednek el [5].

\subsubsection{Országos alaphálózat}

Feladata az erőmüvek és a csomóponti nagy transzformátorállomások összekapcsolása, a villamosenergia nagy mennyiségủ szállítása. Az országos alaphálózat vezetékei alakítják ki tulajdonképpen a kooperációs villamosenergia-rendszert. A magyar alaphálózat távvezetékeinek nagyobb hányada ma már $440 \mathrm{kV}$-os, de a $220 \mathrm{kV}$-os hálózat is ennek a részét képezi [5]. 


\subsubsection{Nemzetközi, kooperációs hálózat}

A különböző országok alaphálózatait köti össze, biztosítva ezzel a nemzetközi kooperációs villamosenergia rendszerek kialakulását, a nemzetközi villamosenergia-szállítást. A szokásos feszültségszintek itt $220 \mathrm{kV} 440 \mathrm{kV}$ és $750 \mathrm{kV}$ [5].

\subsection{Hagyományos hálózatok topológiája}

Az egész rendszer folytonosságának biztosítása érdekében, illetve amiatt, hogy a különböző feszültségszintek között átjárhatóság biztosítva legyen transzformátorokat szükséges elhelyezni a hálózaton. Mivel a transzformátorok müködési elve az elektromágneses (Faraday-féle) indukciós törvényen alapul, a fent leírt jellemzőkkel rendelkező elektromos infrastruktúra nem müködtethető egyenárammal. Valószínüleg ez a fő történelmi oka annak, hogy a hagyományos elektromos hálózat váltakozó áramú (AC) rendszer. A tipikus hagyományos villamosenergia rendszer felépítése az 1. ábrán látható. Ezenkívül a hagyományos villamosenergia-rendszerek túlnyomó többségét háromfázisú szimmetrikus rendszerként müködtetik, alapvetően két fő okból. Az egyik gazdasági szempont, ugyanis ugyanannyi energia átvitelének lehetőségét garantálja, mint egyfázisú rendszeren, jelentős szabadvezeték és kábelanyag megtakarításával. A másik ok az, hogy a pillanatnyi teljesítmény állandó, ami rendkívül fontos tényező az indukciós gépek üzemeltetésével kapcsolatban. [1]

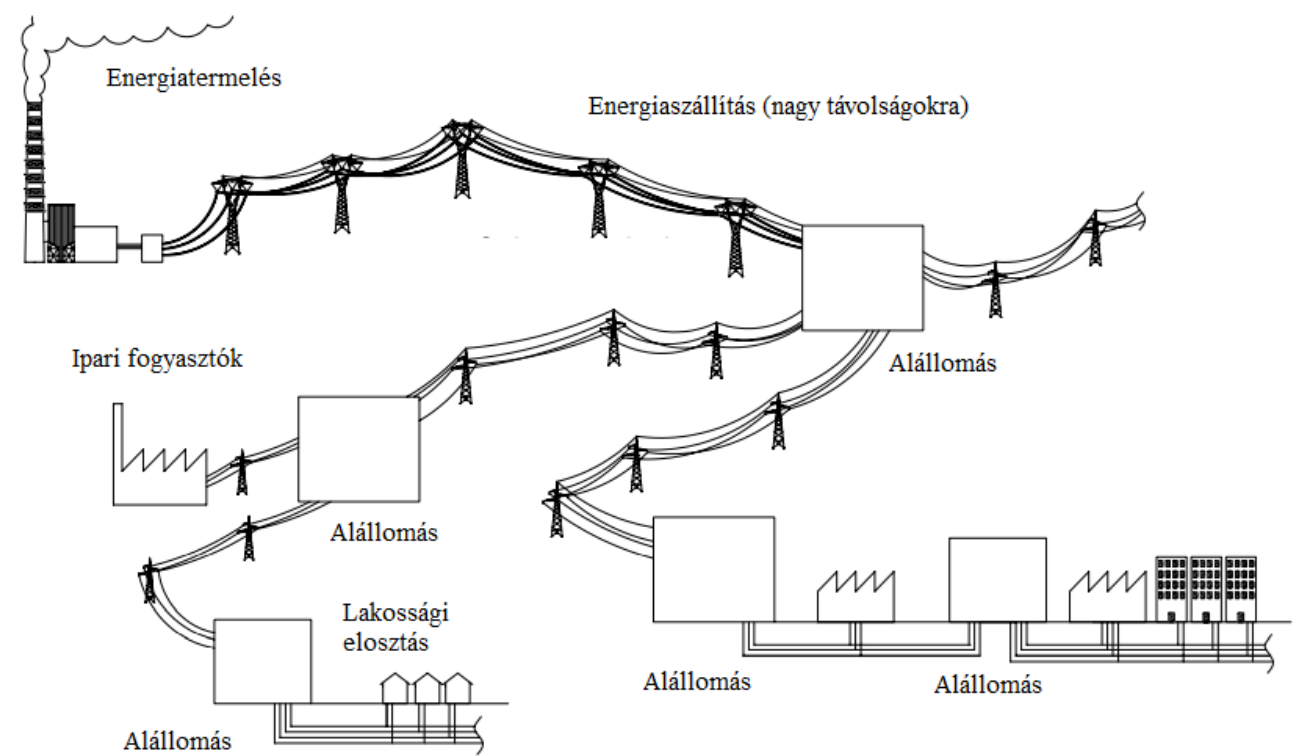

1. ábra. Hagyományos villamos energia rendszer felépitése [2].

\section{Microgrid hálózatok}

A jelenlegi villamosenergia-rendszer gyakorlatilag arra épül, hogy az erőművekből származó villamosenergiát az ipartelepeken és háztartásokban központosított fogyasztókhoz vezesse. Az erőmüvek hatásfokát tekintve, az égési folyamatoknál a primer energia 50-70\%-a hőveszteség, továbbá a hagyományos erőmüveknél 20-25\% extra kapacitás áll csak rendelkezésre, hogy az aktuális fogyasztás követhetö legyen csúcsidőben [2]. 
A jelenlegi villamosenergia-ellátási rendszer másik hátránya a teljes áramkimaradás miatti sebezhetőség, ha tömeges kiesések történnek a hálózat bármelyik részén. Az intelligens hálózat célja, hogy orvosolja a jelenlegi hálózat jelentős gyengeségeit továbbá lehetőséget teremtsen a szolgáltatásban résztvevőknek, hogy folyamatos információ legyen a hálózati elemekről, valamint a hálózat állapotáról és a müködéséről. Az intelligens hálózatok várhatóan rugalmasabbak lesznek bármilyen meghibásodás esetén és számos további előnye van a hagyományos villamosenergia-rendszerekkel szemben. A rendszer egyik jellemzője az energiahatékonyságra való optimalizálás, emellett a környezeti hatások csökkentése is megvalósítható a rendszerrel, amely a megújuló energiaforrásoknál jellemző. Mivel a napenergiával történő villamosenergia-termelés esetén, a nem egyenletes napsütés DC és AC oldalon is feszültségváltozást okoz, továbbá a napelemes inverterek által szolgáltatott feszültség a napelem modulok hőmérsékletének függvényében igen széles skálán mozognak.

Mivel az intelligens hálózat energiahatékonyságra törekszik, ezért az energiaveszteségek csökkenhetnek (pl.: a villamosenergia-rendszeren disszipált hő). A Microgrid hálózatok egymással szoros kapcsolatban álló terhelések és helyi erőmüvek rendszere, amelyek szigetüzemben, a hálózattól függetlenül is müködhetnek, vagy akár a villamos hálózathoz is csatlakoztathatók. A Microgrid hálózatok gyakorlatilag a hagyományos hálózat összes alapvető elemét tartalmazza, de a rendszer kialakítását tekintve sokkal közelebb helyezkednek el egymáshoz, így az erőműveket és a fogyasztókat tömörebb szerkezetben reprezentálja. Az erőművek szorosan a fogyasztók szomszédságában helyezkednek el, így nincs szükség a hagyományos villamos hálózathoz hasonló átviteli rendszerre. A helyi erőmüvek képesek lehetnek kielégíteni a helyi igényeket, ellenkező esetben az áramhiányt egy nagyobb, a Microgrid hálózatokat összekötő villamos hálózat kompenzálja. Más szavakkal, a Microgrid hálózatok a hagyományos hálózat kicsinyített változata, viszont rendelkeznek kommunikációs hálózattal, valamint vezérlőrendszerrel is, amely lehetővé teszi, hogy a rendszer irányítható legyen [2].

A Microgrid hálózatok felépítését több oldalról lehet megközelíteni. Az egyik elgondolás szerint a hálózatba integrálni kell a megújuló energiaforrásokat a környezeti hatások miatt, a másik megközelítés szerint az energiabiztonság és a megbízhatóság alapvető tényezőit kell figyelembe venni, amelyek megkövetelik, hogy a Microgrid hálózatok nagyobb biztonsággal müködő hálózathoz kapcsolódjanak. Talán a két megközelítés együtt a legmegfelelőbb.

Az intelligens Microgrid hálózatok struktúráját úgy tervezik meg, illetve alakítják ki, hogy csatlakoztatható, valamint leválasztható legyen a közüzemi villamos hálózatról, ezáltal az intelligens vezérlö rendszer lehetőséget biztosít arra, hogy a villamosenergia-termelés és annak felhasználása optimalizálva legyen. Az intelligens Microgrid hálózat olyan elektromos hálózat, amely különféle funkciójú és energia mérésekkel kapcsolatos eszközöket és rendszereket tartalmaz, beleértve az intelligens fogyasztásmérőket, az intelligens készülékeket, a megújuló energiaforrásokat és az energiahatékony erőforrásokat. A 2.ábra a Microgrid hálózatok alapvető részeit mutatja. A két rendszer autonóm, de mégis egymással összefüggő kapcsolatban áll. Az egyik cél az energia eljuttatása a termelési ponttól a fogyasztóig, a másik pedig az összekapcsolt rendszerek szabályzása, illetve a hálózati adatok alapján az energiagazdálkodás optimális kialakítása.

A fogyasztók és Microgrid hálózat helyi energiaforrásai egyetlen vezérelhető rendszerként müködik, amely villamos energiát és hőenergiát is biztosít az adott helyi területnek. Ebből az következik, hogy ezt a hálózatot intelligens eszközök és infrastruktúra jellemzik. A Microgrid hálózatban lévő eszközök három fö kategóriába sorolhatók:

- Elosztott energiaforrások (külföldi szakirodalmakban: DER-Distributed Energy Resources)

- Elosztott tárolás (külföldi szakirodalmakban: DS- Distributed Storage)

- Fogyasztók (mind villamosenergia és hőenergia tekintetében) [1] 


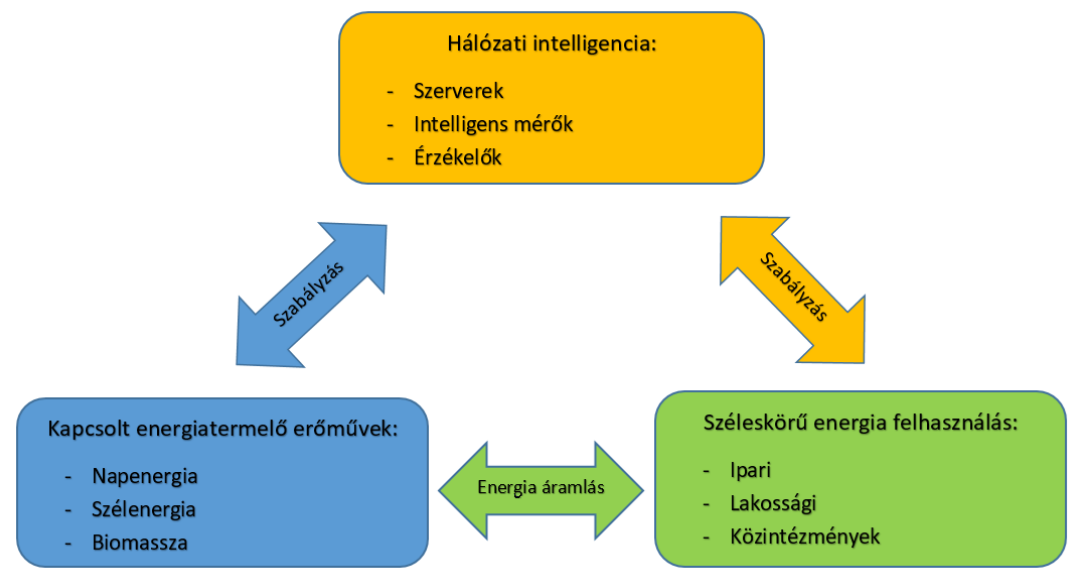

2. ábra. A Microgrid hálózatok alapvetö részei [2].

Az elosztott energiaforrásokat (DER) további két részre lehet bontani, a Megújuló energiaforrások (külföldi szakirodalmakban: RES-Renewable Energy Sources), valamint Hagyományos energiaforrások (CES Conventional energy sources). Ez sokféle energiaforrást jelent, valamint sok termelési típust, amelyet elosztott termelésnek neveznek (DG-Distributed generation). Hálózati infrastruktúra szempontjából jellemzően rendelkezik villamosenergia hálózattal, termikus infrastruktúrával, valamint információs, kommunikációs infrastruktúrával. A villamos és termikus infrastruktúra összekapcsolódik, ha kapcsolt energiatermeléssel (CHP-Combined Heat and Power) történik az energia előállítása az intelligens hálózatban. Továbbá a kommunikációs hálózat, illetve a vezérlő rendszer lehetővé teszi, hogy az összes eszköz a hálózatban optimálisan legyen kezelve. Fontos elemei még a Microgrid hálózatnak a leválasztó és védelmi eszközök, a közös csatlakozási ponton (PCC-Point of Common Coupling). Ez az a pont, ahol a villamos hálózathoz csatlakozik a Mirogrid hálózat. A 3. ábra a Microgrid hálózatok általános felépítését mutatja [1].

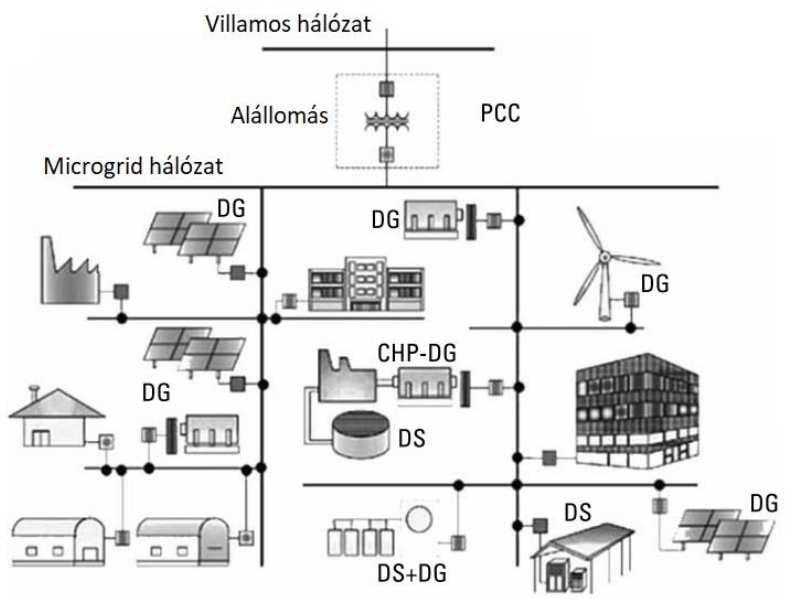

$$
\begin{gathered}
\text { PCC - Point of Common Coupling } \\
\text { (Közös csatlakozási pont) } \\
\mathrm{CHP} \text { - } \begin{array}{l}
\text { Combined Heat and Power } \\
\text { (Kapcsolt energiatermelés) }
\end{array} \\
\mathrm{DG} \text { - } \begin{array}{l}
\text { Distributed Generation } \\
\text { (Elosztott termelés ) }
\end{array} \\
\mathrm{DS} \text { - } \begin{array}{c}
\text { Distributed Storage } \\
\text { (Elosztott tárolás) }
\end{array}
\end{gathered}
$$

3. ábra. Microgrid hálózat általános felépitése [1]. 


\subsection{A Microgrid hálózatok általános felépítése}

A vezérlés és szabályozás biztosítja a Microgrid hálózatok gazdaságos müködését. Ezek különböző szabályozási módszerekkel valósíthatók meg. A 4. ábra a Microgrid hálózatok kapcsolódását mutatja a közüzemi hálózathoz. Az MGCC (Microgrid Central Controller), amely a Microgrid hálózat központi vezérlője, amely a villamosenergia hálózat vezérlésével biztosítja az energia elosztását a rendszeren belül. A Microgrid hálózatokban a mikroforrás-vezérlök (külföldi szakirodalmakban: MCMicrosource Controller) és a terhelés-szabályozók (külföldi szakirodalmakban: LC-Load Controller) felelősek az elosztott források és a vezérelhető terhelések a hálózathoz történő csatlakoztatásáért és vezérléséért. A mikroforrás-vezérlők és terhelés-szabályozók helyi szinten müködnek, míg a Microgrid hálózat központi vezérlöje (MGCC) központi irányítóeszközként müködik [4, 6].

\subsubsection{Microgrid hálózat központi vezérlö}

Feladata a központi vezérlés. Felelős azért, hogy az energiaegyensúly megmaradjon a fogyasztás és a termelés között amellett, hogy minimalizálja az energiaveszteségeket és maximalizálja a Microgrid hálózat hatékonyságát.

\subsubsection{Mikroforrás vezérlö}

Helyi információk felhasználásával a Mikroforrás vezérlőnek képesnek kell lennie a feszültség- és teljesítmény szabályozására a terhelés változására vagy annak zavarára reagálva. A csatlakoztatott energiaforrástól függetlenül képes a gyors reagálásra és beavatkozásra.

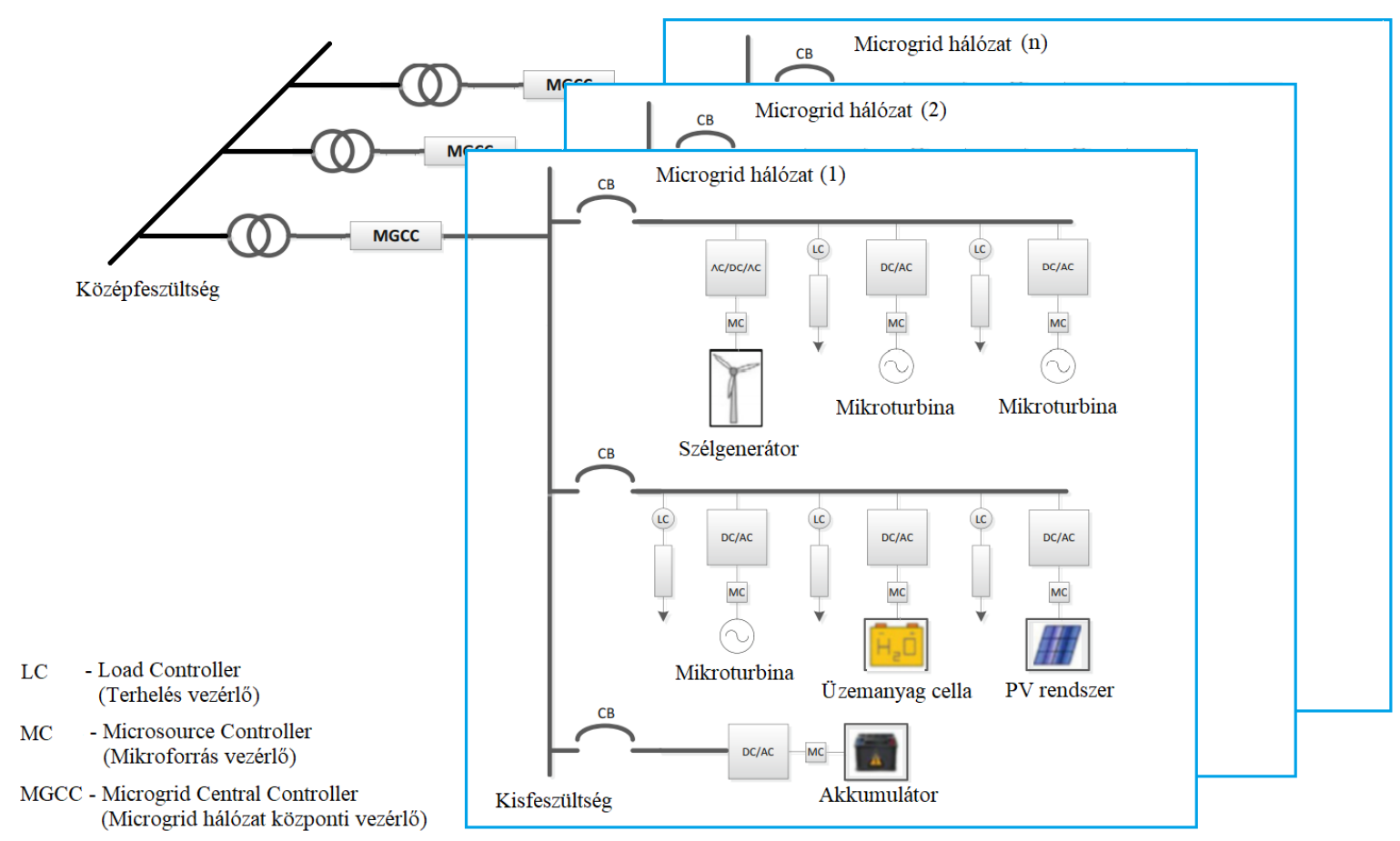

4. ábra. Microgrid hálózatok kapcsolódása a közüzemi hálózathoz [4]. 


\subsubsection{Terhelés-szabályzó}

Egyes berendezések csatlakoztatásával, illetve leválasztásával terhelésirányítást tud végezni bizonyos előre meghatározott időszakokban. A szabályozással a Microgrid hálózat kedvezőtlen müködési körülményeit csökkenti [4].

\subsection{A Microgrid hálózatok csoportosítás alkalmazás szerint}

Hálózatra csatlakoztatott vagy szigetüzemre is képes Microgrid hálózatok jellemzően háromfázisú váltakozó áramú rendszeren keresztül csatlakoznak a közüzemi hálózathoz. A teljesítményelektronika fejlődésével az egyenáramú rendszerek alkalmazása is elterjedt ezen a területen. Attól függően, hogy milyen a fogyasztói igény, áramnem szempontjából többféle Microgrid hálózat, AC, DC és Hibrid Microgrid hálózat is kialakítható [2].

\subsubsection{AC Microgrid hálózatok}

Az AC Microgrid hálózatok nagyon hasonlítanak a hagyományos hálózathoz, azzal a különbséggel, hogy ezeknél az energia megtermelését helyben végzik, vezérlőkön keresztül a helyi fogyasztokhóz eljuttatva a villamos energiát. Szinte az összes áramforrás elektromos átalakítókon keresztül csatlakozik az AC hálózathoz. Az ilyen típusú Microgrid hálózatok egyik fö korlátja az DC felhasználáshoz szükséges további átalakítás. A főbb energiaforrások kimenetei egyenáramúak, és ezeknek többfokozatú átalakításra van szükség, hogy szinkronizálható legyen a váltakozó áramú hálózaton történő folyamatos müködéshez. A gyorsan növekvő egyenáramú fogyasztók, például a LED-es lámpák, az információ-technológiai és szórakoztatóelektronikai eszközök és készülékek akkumulátortöltői több szintủ AC-DC átalakítással nyernek villamos energiát, ezzel sajnos csökken a rendszer hatásfoka.

Az 5.ábra mutatja egy tipikus AC Microgrid hálózat felépítését. [2, 3]

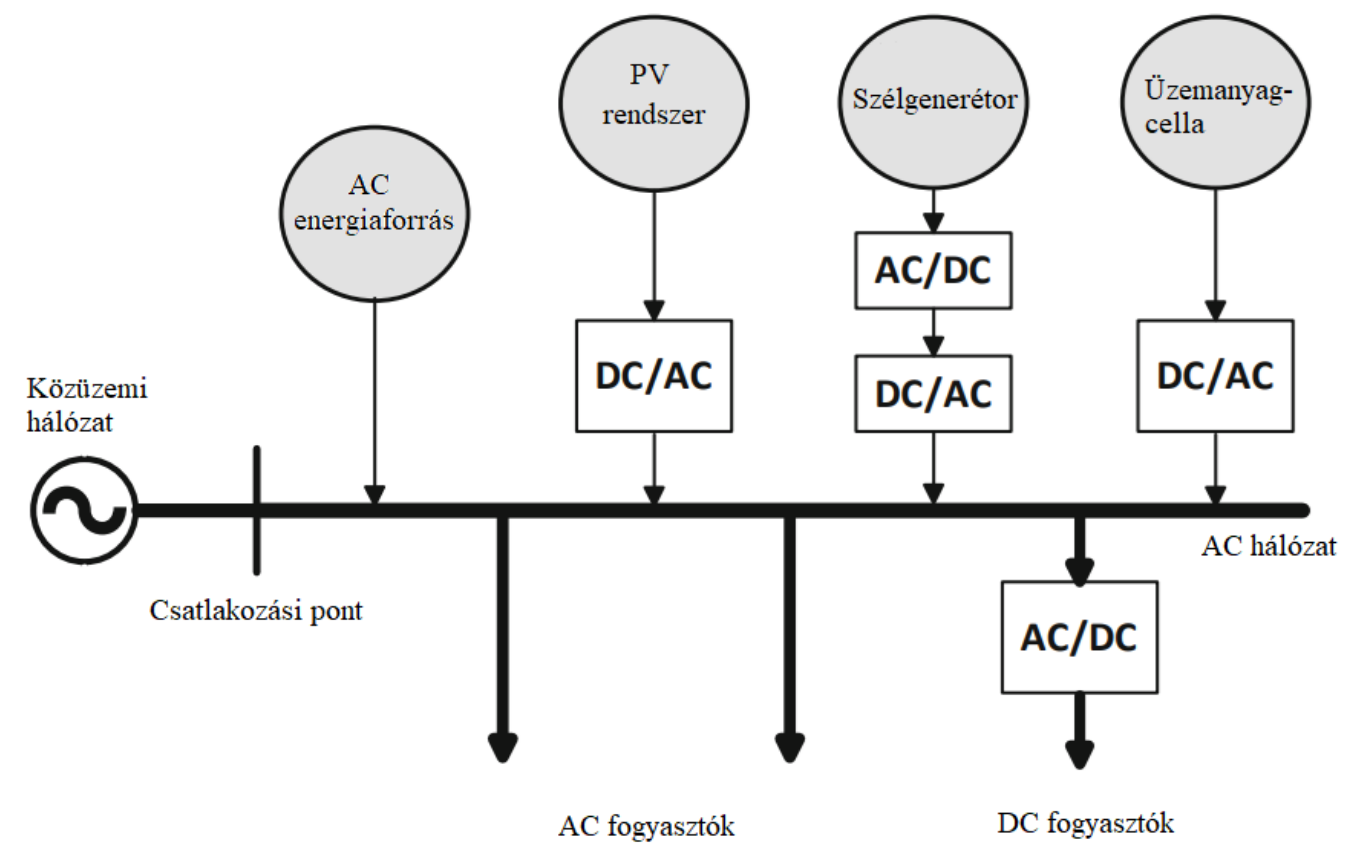

5. ábra. AC Microgrid hálózat felépitése [2]. 


\subsubsection{Microgrid hálózatok}

Az elmúlt években a megújuló energiaforráson alapuló rendszerek, például a fotovoltaikus rendszerek, illetve az üzemanyagcellák gyors növekedése miatt, továbbá az elektronikai eszközök és az egyenáramú fogyasztók következtében az alacsony feszültségü egyenáramú Microgrid hálózatok népszerüsége növekedni látszik [2].

A DC Microgrid hálózatok legfőbb elönye az AC rendszerekhez képest az, hogy a villamosenergia áramlás egyirányú. Ez lehetôvé teszi az áramlás egyszerü szabályozását a rendszerben található teljesítményelektronikai átalakítók vezérlésével. A teljesítmény áramlásának iránya szorosan összefügg az áramerősség és a feszültség irányával. Ennélfogva a teljesítményszabályozás az áramerősség szabályozásával lehetséges. Ezért a DC Microgrid hálózatok az utóbbi években fontos vizsgálati tárgy lett, mivel megbízhatóbbak és alacsonyabbak a veszteségeik. Mivel az egyenáramú hálózatokra nincs szabvány, és nincs sok olyan eszköz vagy termék, amely egyenáramot használna tápforrásként, illetve egyenáramú csatlakozással rendelkezik, emiatt a DC Microgrid hálózatok egyetlen ponton csatlakoznak a váltakozó áramú közüzemi hálózathoz. A 6. ábra mutatja egy tipikus DC Microgrid hálózat felépítését [2, 3, 7].

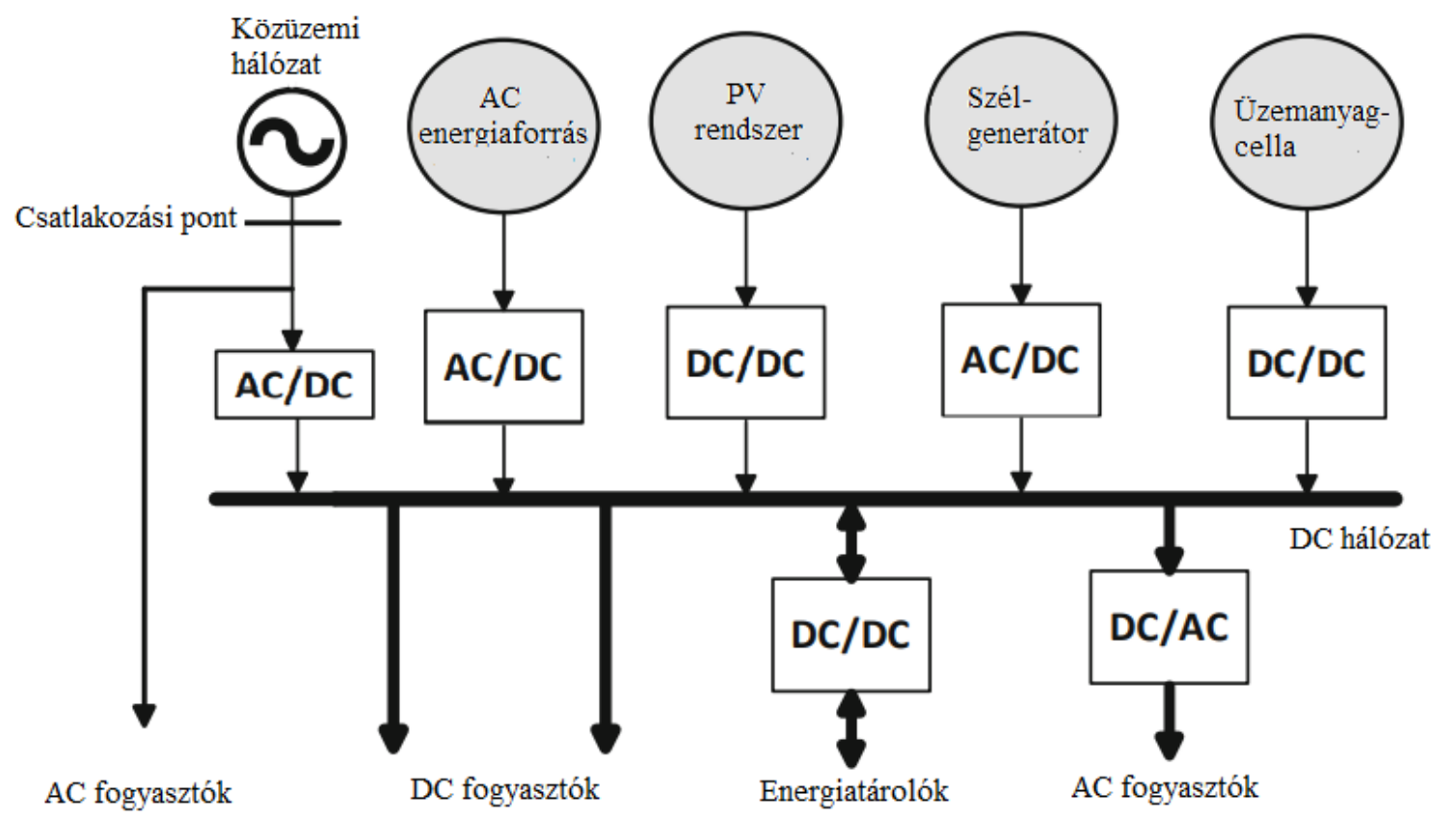

6. ábra. DC Microgrid hálózat felépitése [2].

\subsubsection{Hibrid Microgrid hálózatok}

A hibrid Microgrid hálózatok egyesítik az AC és DC Microgrid hálózatok előnyeit. A rendszer rendelkezik AC és DC alhálózattal, villamosenergia-termelő eszközökkel és fogyasztókkal mindkét alhálózaton. Egy tipikus hibrid Microgrid hálózat felépítését mutatja a 7.ábra.

A rendszerben minimalizálva van a DC-AC, illetve az AC-DC átalakítás ezáltal az üzembiztonság növekszik és a hatásfok jobb, valamint alacsonyabb költségeket jelent a rendszer egészét tekintve. A hibrid rendszer lehetőséget kínál arra, hogy az energiaforrások maximális kihasználása érdekében a 
rendelkezésre álló villamos energiát átirányítsa arra helyre, ahol éppen felhasználásra van szükség. Fogyasztói szempontból a hibrid rendszerek rugalmasságot kínálnak abból a szemszögből, hogy AC vagy DC rendszert szeretnénk bővíteni. A jelenlegi váltakozó áramú elosztó hálózat minimális módosítása elegendő lesz az ilyen hibrid rendszerek kialakításához [2, 3, 7].

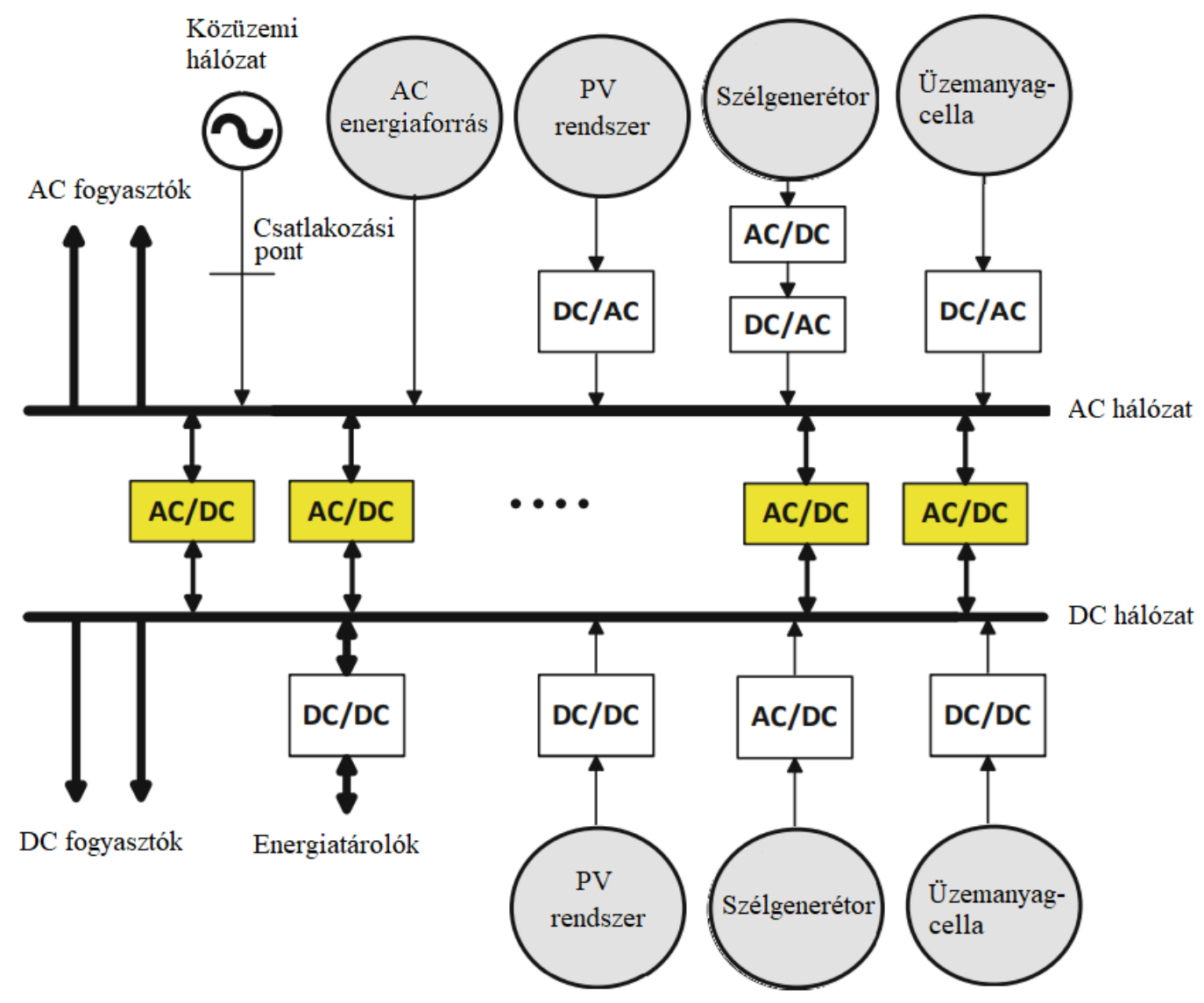

7. ábra. Hibrid kialakitású Microgrid hálózat felépitése [2].

\section{4. Összefoglalás}

A jelenlegi villamosenergia-rendszer egyik nagyobb hátránya az, hogy nagy távolságokra szükséges eljuttatni a megtermelt villamosenergiát, ezáltal a veszteség, amely a villamos hálózaton jelentkezik nem elhanyagolható. Másik hátránya a teljes áramkimaradás miatti sebezhetőség. Az intelligens hálózatok várhatóan rugalmasabbak lesznek bármilyen meghibásodás esetén. A rendszer egyik jellemzöje az energiahatékonyságra való optimalizálás, emellett a környezeti hatások csökkentése megvalósítható a rendszerrel a megújuló energiaforrások miatt. Mivel az energiahatékonyságra törekszik, ezért a hálózaton az energiaveszteségek csökkenhetnek.

A Microgrid hálózatok többféle kombinációja ad lehetőséget a rendszer optimális kialakítására, de a hibrid rendszerek bizonyulnak a legrugalmasabb megoldásnak a jelenlegi villamosenergia-hálózat átalakíthatóságának és az intelligens hálózatok vezérelhetőségének szempontjából. 


\section{Irodalom}

[1] Federico Delfino, Renato Procopio, Mansueto Rossi, Stefano Bracco, Massimo Brignone, Michela Robba, Microgrid Design and Operation, 2018, ISBN 13: 978-1-63081-150-1

[2] Naser Mahdavi Tabatabaei, Ersan Kabalci, Nicu Bizon, Microgrid Architectures - Control and Protection Methods, 2020, ISSN 1860-4676 https://doi.org/10.1007/978-3-030-23723-3

[3] Sasi K. Kottayil, Smart Microgrids, 2020, ISBN: 9780429325274 https://doi.org/10.1201/9780429325274

[4] Antonio Carlos Zambroni de Souza, Miguel Castilla, Microgrids Design and Implementation, 2019, ISBN 978-3-319-98687-6 https://doi.org/10.1007/978-3-319-98687-6

[5] Dr. Novothny Ferenc, Villamosenergia-ellátás II. Budapest, 2002

[6] Professor Nikos Hatziargyriou, Microgrids Architectures and Control, 2014, ISBN: 978-1-11872068-4

[7] Magdi S. Mahmoud, Microgrid Advanced Control Methods and Renewable Energy System Integration, 2017, ISBN: 978-0-08-101753-1 